Lima: IEP, Lima, 2008, 280 pages

\title{
Carlos Galdo, Juan. Alegoría y nación en la novela peruana del siglo $X X$
}

Marcel Velazquez Castro

\section{(2) OpenEdition}

\section{Journals}

\section{Edición electrónica}

URL: http://journals.openedition.org/bifea/3164

DOI: 10.4000/bifea.3164

ISSN: 2076-5827

\section{Editor}

Institut Français d'Études Andines

\section{Edición impresa}

Fecha de publicación: 1 agosto 2008

Paginación: 406-407

ISSN: 0303-7495

\section{Referencia electrónica}

Marcel Velazquez Castro, "Carlos Galdo, Juan. Alegoría y nación en la novela peruana del siglo XX», Bulletin de l'Institut français d'études andines [En línea], 37 (2) | 2008, Publicado el 01 febrero 2009, consultado el 27 noviembre 2020. URL : http://journals.openedition.org/bifea/3164 ; DOI : https:// doi.org/10.4000/bifea.3164

\section{(c)}

Les contenus du Bulletin de l'Institut français d'études andines sont mis à disposition selon les termes de la licence Creative Commons Attribution - Pas d'Utilisation Commerciale - Pas de Modification 4.0 International. 


\section{Juan Carlos GALDO. Alegoría y nación en la novela peruana del siglo $X X$. IEP, Lima, 2008, 280 p.}

\section{LAS NOVELAS DE LA NACIÓN}

Este libro de Juan Carlos Galdo ofrece una lectura comprensiva y coherente de la novela peruana escrita en el siglo XX, con énfasis en las relaciones entre las peripecias de los personajes y las características de las colectividades del mundo representado. Las seis novelas elegidas: El Tungsteno, El mundo es ancho y ajeno, El Sexto, Conversación en la Catedral, Redoble por Rancas, y La violencia del tiempo construyen diversas imágenes alegóricas de la nación, pero todas ellas: a) ofrecen formas de des/articular la pertenencia del individuo a la comunidad, y b) exhiben los límites del paradigma mimético verosímil. Una línea del argumento principal asume que los procesos estructurales y las fracturas que configuran el entramado social de la nación se proyectan en el discurso ficcional como alegorías.

El libro es fruto de una tesis doctoral y cumple con dos características convencionales de todo trabajo académico: un marco teórico, en este caso, multidisciplinario, y análisis particulares que ofrecen nuevos conocimientos y validan la pertinencia de la propuesta.

El marco teórico empleado en este libro bebe de diversas fuentes. El autor identifica como tema persistente en la literatura peruana la relación entre el sujeto individual y la colectividad en que se desenvuelve, además de la representación problemática de dicho espacio social. Esto se vincula con la persistencia de la búsqueda de la identidad, atribuida por Aníbal Quijano a la falta de definición histórica que emerge en momentos de crisis. El conflicto por la determinación de la identidad se enmarca, según Antonio Cornejo Polar, bajo la huella de la dominación colonial y de la constitución heterogénea del sujeto latinoamericano. Galdo recupera de Cornejo la categoría de heterogeneidad y la de sujeto plural atravesado por distintas temporalidades e identidades. Por ello, la representación narrativa refleja las rupturas y las fragmentaciones de la realidad y de la identidad anhelada que evoca.

El concepto de alegoría manejado por el autor deriva de las ideas de Walter Benjamin y Paul de Man. Galdo incorpora en su análisis el elemento de la melancolía, tomado de Benjamin, quien sostiene que el melancólico tiende a posar su mirada en los aspectos más ruines y oscuros de la realidad, enfocándose en los fragmentos destruidos por el tiempo. En consecuencia, el escenario para el sujeto enmarcado en la alegoría es la historia. Las relaciones entre nación, temporalidad y narración se presentan desde las conocidas ideas de Anderson, y las críticas y nuevas miradas de algunos teóricos de la poscolonialidad como Bhabha y Chatterjee. Finalmente, se retoma el método de interpretación alegórico de Jameson y la noción de ficciones fundacionales de Sommer. A todas luces, resulta desproporcionado este variopinto arsenal teórico para la comprensión hermenéutica presentada en el cuerpo central del trabajo, y para las escuetas conclusiones que se presentan al final del libro.

La hipótesis es el flanco más débil del libro ya que no llega a ser formulada con claridad. El libro se propone leer «un conjunto de novelas peruanas (...) a partir de los modelos de interpretación que ofrecen el tropo de la alegoría y las narrativas de la nación» (16). Esto es un programa de trabajo, que se desarrolla con provecho y erudición en los marcos conceptuales trazados, pero sin la fuerza y la dirección que toda buena hipótesis posibilita. 
Los análisis particulares identifican procesos y elementos importantes en la producción de las novelas y en sus campos de significación. A veces, la travesía por los contextos socioculturales y políticos, y el diálogo de la novela con la sociedad termina adquiriendo mayor relevancia que la propia interpretación textual. Debe señalarse el amplio y eficiente manejo de las fuentes secundarias que posibilita inscribir los análisis de Galdo en la tradición crítica latinoamericana, pero que en ocasiones termina restringiendo por el peso de la autoridad las posibilidades y hallazgos más originales del libro.

La lectura propuesta de la fundacional novela de Alegría El mundo es ancho y ajeno se inscribe en la tradición crítica de Cornejo Polar y Peter Elmore. El aporte de Galdo es considerar la figura de Benito Castro desde la perspectiva del héroe alegórico (la peregrinación, la visión de su destino, los obstáculos que supera, la autoconciencia de su destino y el final apocalíptico) lo configuran como un héroe modernizador que formaliza el futuro, las violentas transformaciones de las comunidades indígenas lideradas por los nuevos sujetos sociales: mestizos y cholos.

Considerar que la célebre novela Conversación en La Catedral puede ser leída en clave escatológica-alegórica es un acierto destacable. La perrera, el propio bar, los burdeles, los antros nocturnos que ofrecen ese escape vacío e inútil para el desencantado Zavalita pueden y deben correlacionarse, es una lástima que el autor solo brinde algunos apuntes en dicha dirección. La mirada melancólica y abisal de Zavalita, y las nuevas luces para comprender al personaje Ambrosio también constituyen novedosos elementos para la comprensión de esta novela. Sin embargo, todos los aportes críticos terminan diluyéndose en una interpretación convencional que sigue los marcos establecidos por la crítica latinoamericana.

Los aportes más sólidos y originales del libro aparecen en las novelas que han sido consideradas de menor valía por la crítica tradicional. Recuperar la novela de Vallejo y colocarla en una serie de novelas representativas del siglo XX es un riesgo que el autor afronta con éxito. Argumenta que El Tungsteno es una novela que ocurre en un espacio andino sin referentes reales, el Cuzco de Vallejo ocupa el centro de la Sierra y ello no es un error, ya que en el mapa cognitivo vallejiano Cuzco sigue en el centro, como el «Moscú milenario». Finalmente, la importancia asignada a la escena de la mujer indígena violada mientras el niño testigo dibuja el escudo de la patria abre un haz de interpretaciones que enriquecen la textura y la trama de una novela que está más allá de las miserias ideológicas del realismo socialista.

En El Sexto de Arguedas, el ojo crítico de Galdo identifica una correlación entre el crudo realismo de sus páginas y el mito del Inkarrí. Esa «visión desencantada, escatológica, infernal» anuncia ya en sus páginas la muerte del universo simbólico del orden social que EI Sexto fundamenta. El devenir y los discursos de Gabriel y Alejandro Cámac adquieren otra densidad desde la estructura mítico-estética de los relatos de la utopía andina.

Este es un libro erudito y útil para pensar la producción de la novela peruana del siglo XX y sus complejas formas de representar nuestras identidades y nuestros conflictos. Además, constituye un buen ejemplo de las nuevas tendencias críticas que están renovando desde la academia norteamericana y en diálogo con la crítica local las formas de leer y comprender la historia literaria peruana. 